\title{
Plasma gonadotrophin concentrations during the oestrous cycle and after ovariectomy in two breeds of sheep with low and high fecundity*
}

\author{
A. Lahlou-Kassi, D. Schams $\dagger$ and P. Glatzel \\ Department of Reproduction and Artificial Insemination, Institut Agronomique \\ et Vétérinaire Hassan II, Agdal-Rabat, Morocco \\ and †Institut für Physiologie, Südd. Versuchs- und Forschungsanstalt für Milchwirtschaft, \\ Technische Universität München, 8050 Freising-Weihenstephan, West Germany
}

\begin{abstract}
Summary. LH and FSH concentrations were measured during the oestrous cycle in two local Moroccan breeds of sheep with low (Timahdite: $1 \mathrm{CL} /$ cycle) and high (D'man: 3 $\mathrm{CL} /$ cycle) ovulation rates. Twenty ewes were used from each breed and blood was collected at 3- or 6-h intervals from 5-4 days before oestrus up to Day 14 of the new cycle, when 4 D'man and 4 Timahdite ewes were ovariectomized. After surgery, blood sampling was continued at 6-h intervals for 2 weeks. (1) The mean basal concentration of $\mathrm{LH}$, the maximum value of the preovulatory $\mathrm{LH}$ surge and the area under the curve were significantly higher $(P<0.05)$ in Timahdite than in D'man ewes. (2) The pattern of FSH in each breed showed no clear basal level but a periodic succession of peaks with variable amplitudes. The first and highest peak corresponded with the preovulatory LH surge. The 2 nd peak followed immediately after the first peak and reached its maximum $24-30 \mathrm{~h}$ later. The 3 rd peak was flatter and occurred around Day 6 of the cycle. The 4th peak was observed around Day 10 of the cycle and showed the lowest amplitude. The 5 th and last peak occurred $66-87 \mathrm{~h}$ before the next preovulatory surge. (3) FSH concentrations were higher in the prolific D'man than in Timahdite ewes around the time of oestrus (pro-oestrous peak, preovulatory surge and the 2nd peak). The drop in FSH concentrations observed in D'man ewes before the preovulatory surge was more pronounced and started later. (4) After ovariectomy there was a rapid increase in $\mathrm{LH}$ and FSH concentrations. The maximum values reached after ovariectomy were similar in the two breeds
\end{abstract}

\section{Introduction}

Several studies have been conducted on the relationship between circulating gonadotrophins and prolificacy in the lamb and adult sheep. Most authors have found a positive correlation between concentrations of LH and FSH and the prolificacy of a breed (see review by Land \& Carr, 1979). Others (Land, Pelletier, Thimonier \& Mauleon, 1973; Quirke, 1979) reported that only the interval between the beginning of oestrus and the discharge of $\mathrm{LH}$ was correlated with the ovulation rate, but that the quantity of $\mathrm{LH}$ discharge, the duration of the preovulatory surge and the peak concentration of LH were not correlated. Bindon, Blanc, Pelletier, Terqui \& Thimonier (1979) found that the ovulation rate is independent from the concentration of plasma LH as well as from FSH measured before and after luteolysis (induced by prostaglandin injection). In contrast, Cahill 
et al. (1981) observed that the second FSH peak, occurring 20-30 h after the preovulatory surge of LH, is significantly higher in the prolific Romanov sheep than in Ile-de-France sheep.

These results need to be confirmed for two reasons. (1) Most authors have used only a small number of animals in their experiments. Also, the difference of ovulation rate between prolific sheep and controls was relatively small and some of the control sheep had the same number of ovulations as the prolific sheep. In the present study we have compared the concentrations of circulating gonadotrophins (FSH and $\mathrm{LH}$ ) during the oestrous cycle and after ovariectomy in two breeds of sheep (D'man and Timahdite) which, even in the same environment, show distinctly different prolificacy and ovulation rates (Lahlou-Kassi, 1980; Lahlou-Kassi \& Marie, 1981).

\section{Materials and Methods}

\section{Animals}

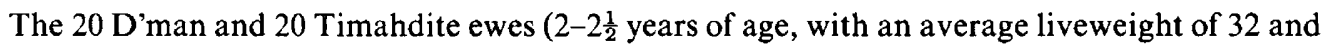
$40 \mathrm{~kg}$ respectively) used in this experiment were taken from a flock kept for at least 5 years on the farm. The animals were randomly bred and were the progeny of 5 rams used for controlled matings. The animals were housed in the same stable and received the same food (green forage and concentrate).

Oestrus was checked twice a day, by using a teaser ram, between July and November to establish cyclicity of the ewes. At the beginning of September the cycles of all animals were synchronized by using subcutaneous implants containing $375 \mathrm{mg}$ progesterone in a silicone elastomer matrix (Sil-Estrus: Abbott Laboratories, North Chicago, IL, U.S.A.). After removal of the implant the animals became oestrous 3-5 days later. For histological evaluation of folliculogenesis, ovariectomy was performed starting on Day 1 of the oestrous cycle, on 2 ewes every 1-2 days. Afterwards these animals were withdrawn from the blood sampling protocol and are the reason for the decrease in the number of animals per group at the end of the cycle.

\section{Blood sampling}

Blood sampling of all ewes started on the morning of Day 15 after removing the implant. Samples were withdrawn at 3 -h intervals for 10 days, and at 6 -h intervals for another 10 days. This sampling for 20 days covered the pro-oestrous, oestrous and luteal-phase period in the majority of ewes. In addition, blood was collected from 4 D'man and 4 Timahdite ewes at 6-h intervals for 2 more weeks after ovariectomy at the end of the previous sampling period. Blood $(8 \mathrm{ml})$ was collected from the jugular vein by needle puncture into heparinized vacutainers and centrifuged at $3000 \mathrm{~g}$ for $20 \mathrm{~min}$. The plasma was immediately frozen and stored at $-20^{\circ} \mathrm{C}$ until assayed for $\mathrm{LH}$ and FSH. The animals showed no clinical effects due to the bleeding procedure.

The ovulation rate (number of corpora lutea) after the second oestrus was determined by endoscopy between Days 5 and 10 .

\section{Hormone determinations}

The concentrations of $\mathrm{LH}$ and FSH were evaluated radioimmunologically as described by Schams \& Karg (1969) and Schams \& Schallenberger (1976).

$L H$. The assay for $\mathrm{LH}$ was a heterologous system using a rabbit antiserum against bovine $\mathrm{LH}$. For radioiodination of pure bovine $\mathrm{LH}$ the chloramine $\mathrm{T}$ method was used. The antiserum showed no cross-reaction with other pituitary hormones and was used at a final dilution of 1/400 000. Total incubation volume of the assay was $0.5 \mathrm{ml}$ when using $0.2 \mathrm{ml}$ of unknown sample. Sensitivity of the assay was $0.25 \mathrm{ng} / \mathrm{ml}$. The intra-assay coefficient of variation (CV) calculated from two control samples running at the beginning, middle and end of the assay was $8.6 \pm 0.7 \%$. The inter-assay 
variation, expressed as the mean of the variation coefficients of 3 different sheep samples, was $11 \cdot 6 \pm 1.8 \%$.

$F \overline{S H}$. The assay for FSH was an homologous system using a guinea-pig antiserum against a pure preparation of sheep FSH (biological activity $31 \times$ NIH-FSH-S1, prepared in our laboratory) that was also used for labelling with the lactoperoxidase method. The slight cross-reaction with ovine LH and TSH was eliminated by adding a constant amount of LH $(10 \mathrm{ng})$ to each tube within the assay. Possible unspecific, interfering influences of sheep plasma were eliminated by adding a constant amount of sheep plasma $(0 \cdot 1 \mathrm{ml}, 1: 9 \mathrm{v} / \mathrm{v}$ diluted with buffer) with a low content of LH to

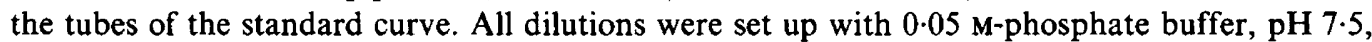
containing $0.18 \%$ EDTA and $0.05 \%$ human serum albumin. Total incubation volume of the assay was $0.5 \mathrm{ml}$ when using $0.3 \mathrm{ml}$ of unknown sample, $0.1 \mathrm{ml}$ diluted antiserum (final dilution $1 / 180000$ ) and $0 \cdot 1 \mathrm{ml}$ labelled FSH. Sensitivity of the assay was $15 \mathrm{ng} / \mathrm{ml}$. The intra-assay CV, calculated from 2 control samples run at the beginning, in the middle and at the end of the assay, was $9.5 \pm 0.6 \%$. The interassay variation obtained from 3 control samples was $13.8 \pm 0.8 \%$.

After incubation for $24 \mathrm{~h}$ at $4^{\circ} \mathrm{C}$, labelled FSH or LH (about $10000-12000$ c.p.m.) was added to each tube. Separation of bound and free hormone was performed by the double-antibody method. A precipitating antiserum against guinea-pig of rabbit gamma-globulin was added after incubation for an additional 48-72 h. Separation of bound from free labelled hormone was performed $24 \mathrm{~h}$ later. $\mathrm{B}_{0}$ was in the range of $40-45 \%$. Ovine pituitary preparations were used as the reference standards for LH (NIH-LH-S13, having a biological activity of $0.93 \times \mathrm{NIH}-\mathrm{LH}-\mathrm{S} 1$ ) and for FSH (NIH-FSH-S12, biological activity $1.25 \times \mathrm{NIH-FSH}-\mathrm{S} 1$ ).

\section{Statistical methods}

The calculation of LH and FSH concentrations was performed on 20 ewes for each breed according to the sampling protocol. Graphs of the plasma concentration for LH and FSH were established for each ewe. The maximum value of the preovulatory LH surge was designated as time zero. For each animal the following values were defined. For LH, the maximum value was determined and the area under the curve of the preovulatory surge was measured by a planimetric method and expressed in $\mathrm{mm}^{2}$. The mean basal concentration during the cycle, i.e. the mean of all the values except for ones corresponding to the surge, was also calculated.

For FSH, the maximum concentration, the area under the curve for each peak and the time of its appearance were calculated. Peaks were identified as when increases of basal concentrations and decreases of elevated concentrations were significant $(P<0.05)$. From these individual values a generalized 'mean standard profile' was established (see Text-fig. 4), in which the lowest and highest FSH concentrations and the intervals from time zero for each ewe were calculated from the individual FSH curve. For all of these characteristics the mean values and their standard errors for each breed were calculated and subjected to an analysis of variance to test the breed effect. Because some ewes were ovariectomized the number of animals available for evaluation of hormonal concentrations decreased during the cycle. The respective number of animals is given within the Text-figures.

\section{Ovulation rate}

\section{Results}

The mean \pm s.e.m. ovulation rate (number of corpora lutea) as determined by endoscopy was $3.05 \pm 0.32$ for D'man and $1.05 \pm 0.05$ for Timahdite ewes $(P<0.001$, for details see Table 1$)$.

\section{Hormone concentrations}

$L H$. The general pattern of $L H$ in the two breeds (Timahdite and D'man) showed a basal level during the luteal phase and a surge during oestrus (Text-fig. 1a). The mean \pm s.e.m. basal 
Table 1. Distribution of ovulation rate (number of corpora lutea) for two breeds of sheep with low and high fecundity

\begin{tabular}{lcrlcccc}
\hline & & \multicolumn{5}{c}{ No. of corpora lutea } \\
\cline { 2 - 7 } \multicolumn{1}{c}{ Breed } & No. of ewes & 1 & 2 & 3 & 4 & 5 & 6 \\
\hline Timahdite & 20 & 19 & 1 & - & 4 & - & - \\
D'man & 20 & 2 & 7 & 4 & 4 & 1 & 2 \\
\hline
\end{tabular}

concentration of LH was $3.32 \pm 0.17 \mathrm{ng} / \mathrm{ml}$ in the Timahdite and $2 \cdot 77 \pm 0.16 \mathrm{ng} / \mathrm{ml}$ in the D'man ewes $(P<0.05)$. A difference occurred immediately before the preovulatory surge and then during the first 7 days of the cycle. During the remaining period of the cycle the concentrations of LH were the same between the two breeds. In addition, the mean \pm s.e.m. maximum concentration of the preovulatory LH surge was $215 \pm 28 \mathrm{ng} / \mathrm{ml}$ in the Timahdite and $132 \pm 20 \mathrm{ng} / \mathrm{ml}$ in the D'man ewes $(P<0.05)$. The area under the curve of the LH surge was also higher $(P<0.01)$ for the Timahdite $\left(4279 \pm 526 \mathrm{~mm}^{2}\right)$ than in the D'man $\left(2239 \pm 320 \mathrm{~mm}^{2}\right)$ ewes.

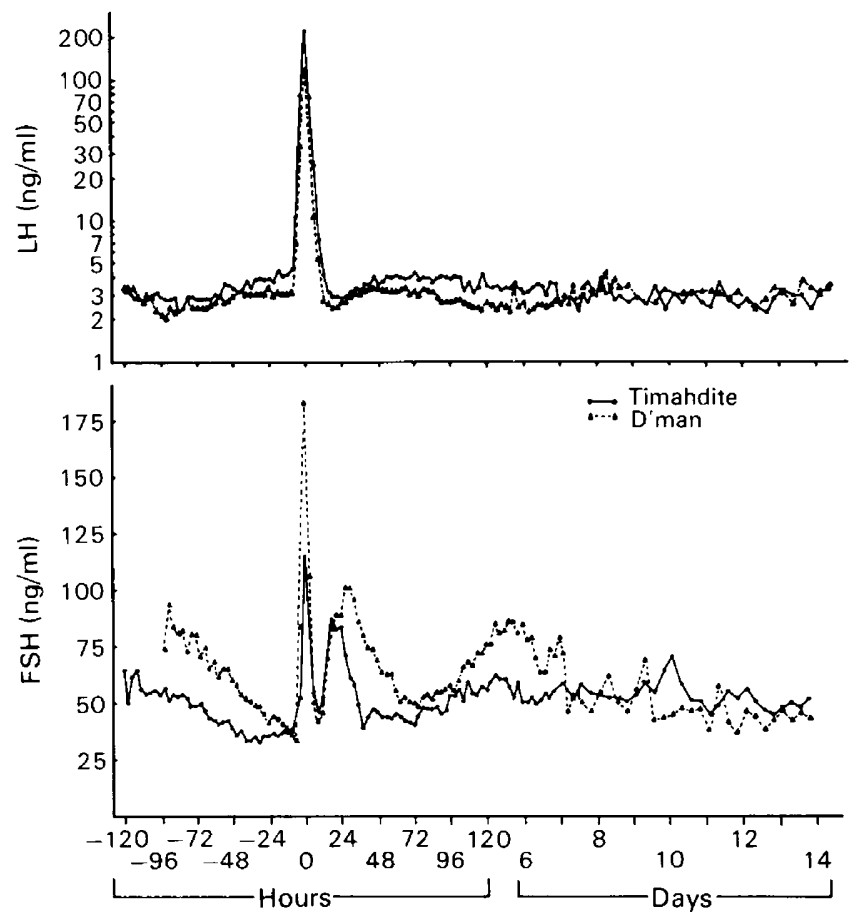

Text-fig. 1. Mean concentrations of LH (NIH-LH-S13) and FSH (NIH-FSH-S12) during the oestrous cycle in D'man and Timahdite ewes. The maximum of the preovulatory LH surge = time zero. Number of animals involved: -96 to $+72 \mathrm{~h}=14-20$ ewes $/ \mathrm{breed} ;+72$ to $+168 \mathrm{~h}$ $=12-16$ ewes/breed $;+168$ to $+264 \mathrm{~h}=6-10$ ewes/breed and +264 to $+336 \mathrm{~h}=4$ ewes/ breed.

$F S H$. The pattern of FSH was quite different from that of LH. As seen in Text-figs 1(b) and 2, there was no obvious basal level but a periodic succession of peaks with variable amplitudes. This pattern was observed in each of the animals tested of both breeds and is more defined in the generalized profile of FSH in Text-fig. 3. The first and highest peak corresponded with the preovulatory LH surge. The second peak followed immediately after the first one and reached 


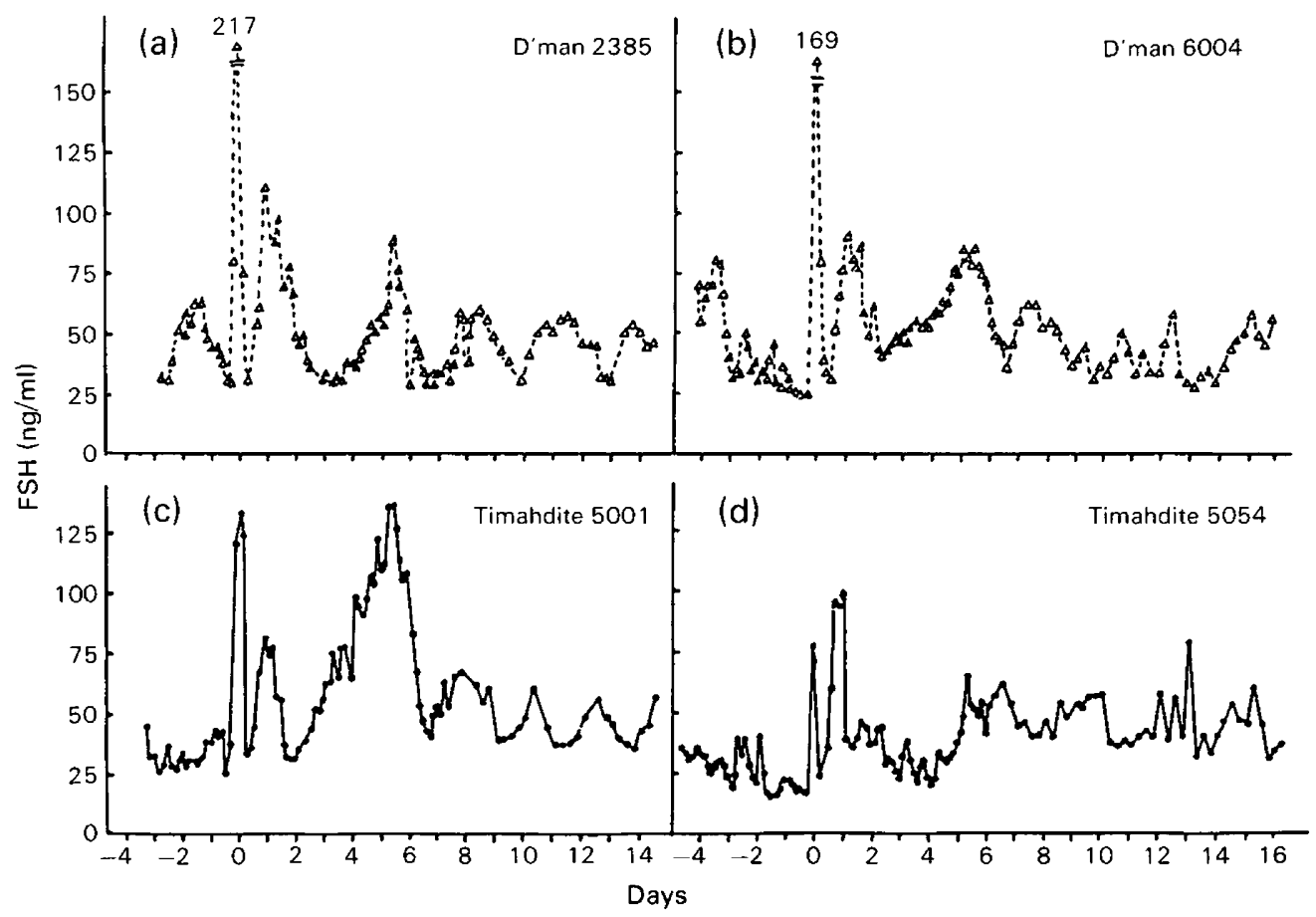

Text-fig. 2. Individual FSH (NIH-FSH-S12) concentrations during the cycle in D'man (a, b) and Timahdite (c, d) ewes. Time $0=$ maximum of preovulatory LH surge.

maximum concentrations 24-30 h later. The third peak was flatter and occurred about Day 6 of the cycle. The fourth peak was observed on Day 10 of the cycle and showed the lowest amplitude. The fifth and last peak occurred 87-66 $\mathrm{h}$ before the next preovulatory LH surge.

Breed variation. Differences between the two breeds in FSH concentrations can be observed for the 'latency time' and absolute values. The 'latency time' was defined as the time lapse between the end of a peak and the beginning of the next peak. It occurred regularly in the Timahdite ewes between the 2 nd and 3rd peaks (F-F' of Text-fig. 3) and the 5th and 1st peaks (B-B' of Text-fig. 3), but was not clearly observed in D'man ewes because of the rapid succession of peaks.

There was also a difference in the maximum value of the preovulatory FSH surge between D'man and Timahdite ewes $(182 \pm 15$ compared to $115 \pm 10 \mathrm{ng} / \mathrm{ml}, P<0.01)$. The second peak was also more pronounced in D'man than in Timahdite ewes $(112.0 \pm 7.0$ compared to $98.0 \pm 6.4 \mathrm{ng} / \mathrm{ml} ; P>0.05)$ and was significant for the area under the curve $(6973 \pm 704$ compared with $3816 \pm 435 \mathrm{~mm}^{2}, P<0.001$ ). In addition, the 5th peak was significantly higher in D'man than in Timahdite ewes $(91 \pm 8$ compared to $66 \pm 7 \mathrm{ng} / \mathrm{ml}, P<0.05)$ and was characterized by a more accentuated decline in the D'man ewes ( $\bar{A}-\mathbf{B}$ in Text-fig. 3 ). There were no differences in the $3 \mathrm{rd}$ and 4 th peaks between the two breeds.

\section{LH and FSH concentrations after ovariectomy}

As shown in Text-fig. 4 there was a rapid increase in plasma LH $(2.5$ to $9 \mathrm{ng} / \mathrm{ml}$ in $24-48 \mathrm{~h})$ and FSH concentrations $(45 \mathrm{ng} / \mathrm{ml}$ to $160-220 \mathrm{ng} / \mathrm{ml}$ in $48-72 \mathrm{~h}$ ) in both breeds after ovariectomy. By 5-6 days after ovariectomy, the increase of hormone concentrations stabilized and reached a plateau. 


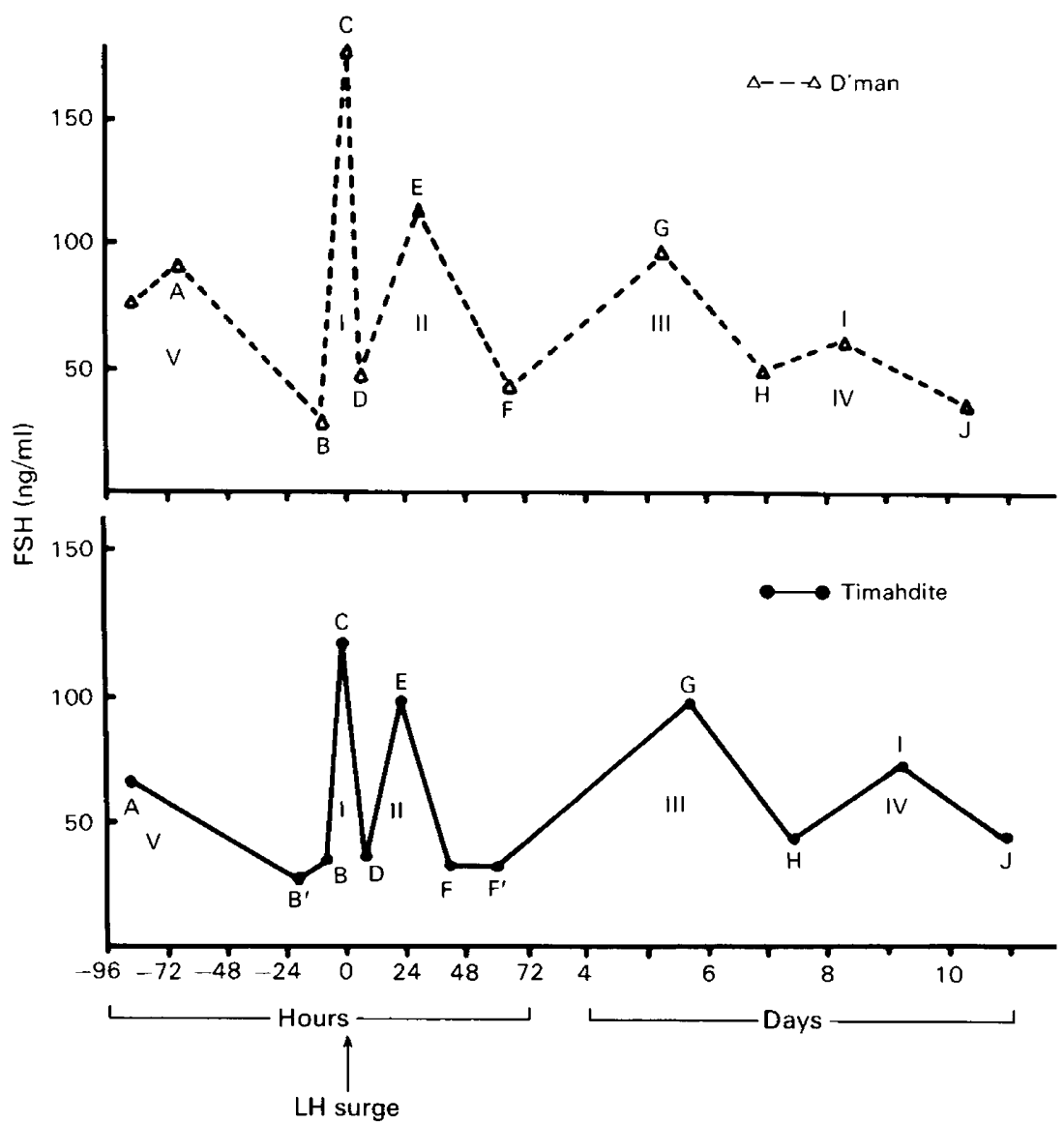

Text-fig. 3. Generalized profile (mean) for the lowest and peak concentrations of FSH and the time relationship to the preovulatory $\mathrm{LH}$ surge during the oestrous cycle in D'man and Timahdite ewes. For no. of animals involved, see Text-fig. 1.

\section{Discussion}

The pattern of LH secretion with a slight increase of basal concentrations 2-3 days before the preovulatory LH surge and a decrease afterwards agrees with earlier reports in the literature (Niswender, Roche, Foster \& Midgley, 1968; Pelletier, Kann, Dolais \& Rosselin, 1968; Goding et al., 1969, Scaramuzzi, Caldwell \& Moor, 1970; Kann, 1971; Hauger, Karsch \& Foster, 1977; Cahill et al., 1981 ; Baird \& McNeilly, 1981). The profile for FSH as observed in both breeds with a peak parallel to the LH surge and a further peak occurring about $20-30 \mathrm{~h}$ later is in agreement with findings in other breeds of sheep (L'Hermite, Niswender, Reichert \& Midgley, 1972; Cumming et al., 1973; Salamonsen et al., 1973; Pant, Hopkinson \& Fitzpatrick, 1977; Bindon et al., 1979; Cahill et al., 1981; Baird \& McNeilly, 1981). However, Miller, Nordheim \& Ginther (1981) did not observe a second FSH peak. After the second FSH peak, a wave-like pattern was shown during the luteal phase, with further peaks on Days 5-6, 9-10 and 14-15. This is in contrast to the observations of most of the preceding authors, who concluded that there is a basal level of FSH with minor fluctuations during the luteal period of the oestrous cycle in sheep. Only Miller et al. (1981) also suggested a wave-like pattern for FSH. The reason for the difference may be as follows. In our 

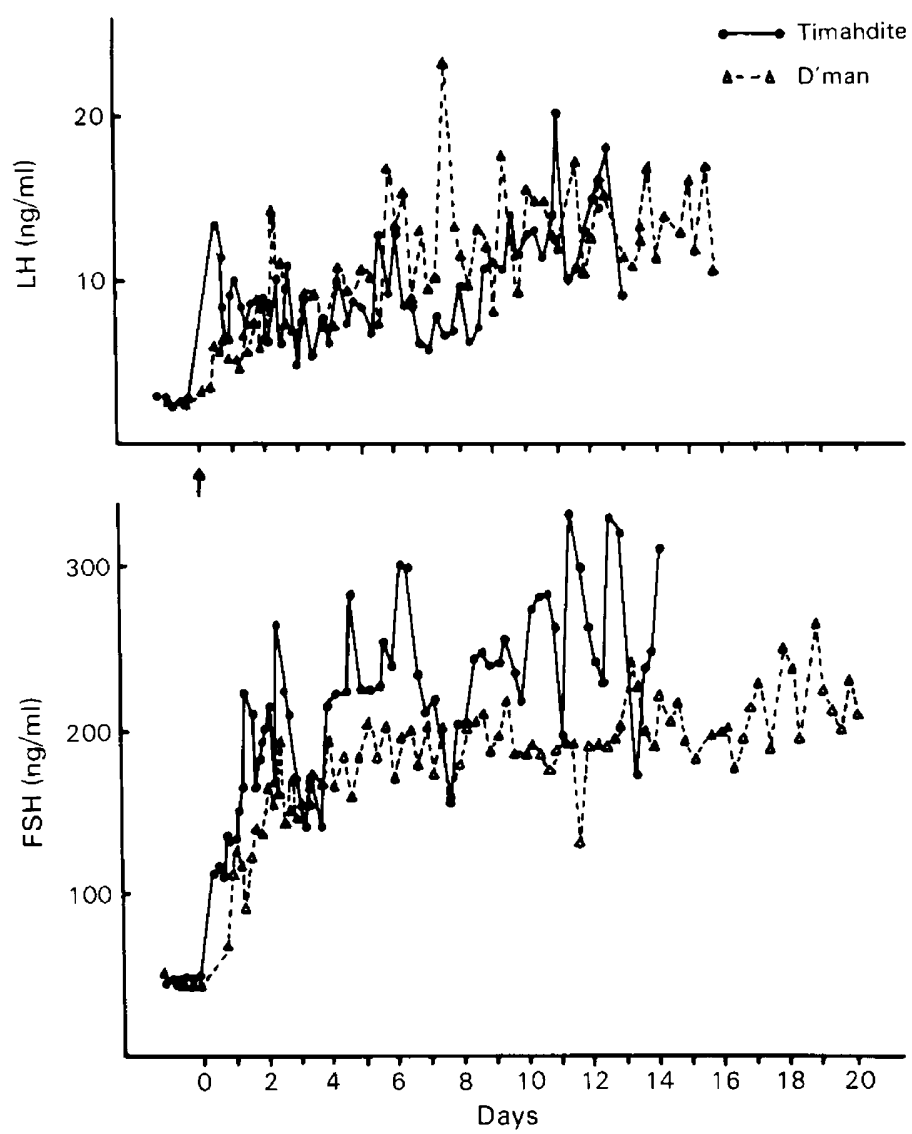

Text-fig. 4. Mean concentrations for LH (NIH-LH-S13) and FSH (NIH-FSH-S12) after ovariectomy (Day 0) in D'man and Timahdite ewes (4/group).

study the interval of blood sampling was relatively short ( 3 or $6 \mathrm{~h}$ ) and the number of animals used per group was high. We analysed the secretion pattern from each individual animal rather than the average for the group. Using only the average secretion pattern it was not possible to demonstrate peaks of FSH during the luteal phase which appear in relation to the preovulatory surge of $\mathrm{LH}$ at different times in different animals. A careful examination of the FSH data of the preceding authors shows that in most of them a wave-like pattern might also be assumed.

By evaluation of FSH data in each individual animal we also found a similar pattern in cattle with peaks at about 4-day intervals (Schams, Toth, Schallenberger, Hoffmann \& Karg, 1976; Schams \& Schallenberger, 1976). The basal concentrations and preovulatory LH surge were significantly lower in the prolific D'man than in the non-prolific Timahdite ewes. Other authors who have measured and compared LH concentrations in sheep breeds of different fecundity did not obtain similar results: only the interval between the beginning of oestrus and the surge of $\mathrm{LH}$ were correlated significantly to the ovulation rate (Land et al., 1973; Bindon, et al., 1979; Cahill et al., 1981). The differences observed here for the LH surge between D'man and Timahdite ewes may be explained by the hypothesis projected by Land (1976), Land, Wheeler \& Carr (1976) and Baird \& McNeilly (1981) that prolific sheep breeds are less sensitive to feedback of oestrogens than are nonprolific sheep breeds.

FSH concentrations were higher in the prolific D'man than in Timahdite ewes, especially around the periovulatory period (pro-oestrous peak and preovulatory surge and for the area under 
the second peak). Cahill et al. (1981) reported similar observations (especially the second FSH peak) and found that the area under the second peak was correlated with the number of antral follicles present in the ovary 17 days later. This suggests that formation of the antrum during the follicular growth phase is under the control of FSH. In contrast, Bindon et al. (1979) did not find any relation between FSH concentrations around oestrus and the number of ovulations.

The secretion pattern of FSH can, to some extent, be correlated to the growth pattern of follicles. As shown by Turnbull, Braden \& Mattner (1977), follicles are growing or regressing asynchronously at any given time during the cycle. Cummins, O'Shea, Bindon, Lee \& Findlay (1983) have reported that the inhibin content of ovaries collected from highly fecund Booroola Merino ewes was only one third of that of control Merino ewes. Cummins et al. (1983) concluded that the feedback relationship of inhibin and FSH in Booroola ewes may be set differently from that in control ewes and this may contribute to the difference in ovulation rate between ewes of the two genotypes.

Another characteristic distinguishes the two breeds and should be considered. The drop in FSH concentrations before the preovulatory surge is more sudden, starts later and is not followed by a 'latency time' in D'man ewes. We assume that this phenomenon may reflect a marked sensitivity to the negative feedback of oestrogens, as shown in sheep (see review by Baird \& McNeilly, 1981). The Timahdite breed may be more sensitive to this negative feedback effect. After ovariectomy there was no longer a difference in FSH concentrations between the two breeds. As shown by Cahill et al. (1981), oestradiol concentrations were higher during pro-oestrus in the prolific Romanov breed and we can assume the same for the D'man breed due to the higher number of large follicles observed during pro-oestrus (unpublished data). The drop in FSH concentrations may also be due to inhibin as assumed for other species (Chappel, 1979; Chappel \& Selker, 1979).

We conclude from the results of the present study that multiple ovulation is related to elevated FSH concentrations during the periovulatory period. Further investigations are needed to elucidate the mechanism initiating these higher concentrations of FSH, especially the negative feedback of oestrogens and the effect of inhibin.

We thank the technical staff of the experimental farm of the Institut Agronomique et Vétérinaire Hassan II and of the Departments for expert assistance; and the National Institutes of Health, Bethesda, U.S.A., for gifts of ovine pituitary standard preparations (NIH-LH-S13 and NIH-FSH-S12).

\section{References}

Baird, D.T. \& McNeilly, A.S. (1981) Gonadotrophic control of follicular development and function during the oestrous cycle of the ewe. J. Reprod. Fert., Suppl. 30, $119-133$.

Bindon, B.M., Blanc, M.R., Pelletier, J., Terqui, M. \& Thimonier, J. (1979) Preovulatory gonadotrophin and ovarian steroid patterns in sheep of breeds with differing fecundity. J. Reprod. Fert. 55, 15-25.

Cahill, L.P., Saumande, J., Ravault, J.P., Blanc, M., Thimonier, J., Mariana, J.C. \& Mauleon, P. (1981) Hormonal and follicular relationships in ewes of high and low ovulation rates. J. Reprod. Fert. 62, 141-150.

Chappel, S.C. (1979) Cyclic fluctuations in ovarian FSHinhibiting material in golden hamsters. Biol. Reprod. $21,447-453$.

Chappel, S.C. \& Selker, F. (1979) Relation between the secretion of FSH during the periovulatory period and ovulation during the next cycle. Biol. Reprod. 21, 347352 .
Cumming, I.A., Buckmaster, J.M., Blockey, M.A., de B., Goding, J.R., Winfield, C.G. \& Baxter R.W. (1973) Constancy of interval between luteinizing hormone release and ovulation in the ewe. Biol. Reprod. 9, 2429.

Cummins, L.J., O'Shea, T., Bindon, B.M., Lee, V.W.K. \& Findlay, J.K. (1983) Ovarian inhibin content and sensitivity to inhibin in Booroola and control strain Merino ewes. J. Reprod. Fert. 67, 1-7.

Goding, J.R., Catt, K.J., Brown, J.M., Kaltenbach, C.C., Cumming I.A. \& Mole, B.J. (1969) Radioimmunoassay for ovine luteinizing hormone. Secretion of luteinizing hormone during estrus and following estrogen administration in the sheep. Endocrinology 85, $133-142$.

Hauger, R.L., Karsch, F.S. \& Foster, D.L. (1977) A new concept for control of the estrous cycle of the ewe based on the temporal relationship between luteinizing hormone, estradiol and progesterone in peri- 
pheral serum and evidence that progesterone inhibits tonic LH secretion. Endocrinology 101, 807-817.

Kann, G.M. (1971) Variation des concentrations plasmatiques de l'hormone luteinisante et de la prolactine au cours du cycle oestrien de la brebis. C. r. hebd. Séanc. Acad. Sci., Paris D 272, 2934-2937.

Lahlou-Kassi, A. (1980) Seasonal variation in oestrus and ovarian activity of two Moroccan breeds: D'man and Timhadite. Proc. 9th Int. Congr. Anim. Reprod. \& A.I., Madrid, Vol. IV, pp. 186-189.

Lahlou-Kassi, A. \& Marie, M. (1981) A note on ovulation rate and embryonic survival in D'man ewes. Anim. Prod. 32, 227-229.

Land, R.B. (1976) The sensitivity of the ovulation rate of Finnish Landrace and Black face ewes to exogenous oestrogen. J. Reprod. Fert. 48, 217-218.

Land, R.B. \& Carr, W.R. (1979) Reproduction in domestic mammals. In Genetic Variation in Hormone Systems, Vol. I, pp. 89-112. Ed. J. G. M. Shire. C.R.C. Press, Florida.

Land, R.B., Pelletier, J., Thimonier, J. \& Mauleon, M. (1973) A quantitatiave study of genetic differences in the incidence of oestrus, ovulation and plasma luteinizing hormone concentration in the sheep. $J$. Endocr. 58, 305-317.

Land, R.B., Wheeler, A.G. \& Carr, W.R. (1976) Seasonal variation in the oestrogen induced $\mathrm{LH}$ discharge of ovariectomized Finnish Landrace and Scottish Blackface ewes. Annls Biol. anim. Biochim. Biophys. 16, 521-528.

L'Hermite, M., Niswender, G.D., Reichert, L.E. Jr \& Midgley, A.R., Jr (1972) Serum follicle stimulating hormone in sheep as measured by radioimmunoassay. Biol. Reprod. 6, 325-332.

Miller, K.F., Nordheim, E.V. \& Ginther, O.J. (1981) Periodic fluctuations in FSH concentrations during the ovine estrous cycle. Theriogenology 16, 669679.

Niswender, G.D., Roche, J.F., Foster, D.L. \& Midgley, A.R., Jr (1968) Radioimmunoassay of serum levels of luteinizing hormone during the cycle and early pregnancy in ewes. Proc. Soc. exp. Biol. Med. 129, 901-904.
Pant, H.C., Hopkinson, C.R.N. \& Fitzpatrick, R.J. (1977) Concentration of oestradiol, progesterone, luteinizing hormone and follicle stimulating hormone in the jugular venous plasma of ewes during the oestrous cycle. J. Endocr. 73, 247-255.

Pelletier, J., Kann, G., Dolais, J. \& Rosselin, G. (1968) Dosage radioimmunologique de lhormone luteinisante plasmatique chez le mouton. Mise au point technique de dosage. $C, r$. hebd. Séance. Acad. Sci., Paris D 266, 2291-2294.

Quirke, J.F. (1979) Control of reproduction in adult ewes and ewe lambs and estimation of reproductive wastage in ewe lambs following treatment with progesterone impregnated sponges and pregnant mare's serum gonadotrophin. Livest. Prod. Sci. 6, 295-306.

Salamonsen, L.A., Jonas, H.A., Burger, H.G., Buckmaster, J.M., Chamley, W.A., Cumming, I.A., Findlay, J.K. \& Goding, J.R. (1973) A heterologous radioimmunoassay for follicle-stimulating hormone: application to measurement of FSH in the ovine estrous cycle and in several other species including man. Endocrinology 93, 610-618.

Scaramuzzi, R.J., Caldwell, B.V. \& Moor R.M. (1970) Radioimmunoassay of LH and estrogen during estrous cycle of the ewe. Biol. Reprod. 3, 110-119.

Schams, D. \& Karg, H. (1969) Radioimmunologische LH-Bestimmung im Blutserum vom Rind unter besonderer Berücksichtigung des Brunstzyklus. Acta endocr., Copenh. 61, 96-103.

Schams, D. \& Schallenberger, E. (1976) Heterologous radioimmunoassay for bovine follicle-stimulating hormone and its application during oestrous cycle in cattle. Acta endocr., Copenh. 81, 461-473.

Schams, D., Toth, G., Schallenberger, E., Hoffmann, B. \& Karg, H. (1976) Relationship between hormonal parameters and ovarian morphology as observed by pelviscopy during the oestrous cycle in cattle. Proc. 8th Int. Congr. Anim. Reprod. \& A. I., Cracow, Vol. III, pp. 192-195.

Turnbull, K.E., Braden, A.W.H. \& Mattner, P.E. (1977) The pattern of follicular growth and atresia in the ovine ovary. Aust. J. biol. Sci. 30, 229-241.

Received 6 May 1983 